\title{
A Few Words on the History of Printing in Friburg, Switzerland.
}

Translated from Centralblatt für Bibliothekswesen, Jan.-Feb., r 898, p. 59.

T $\mathbf{N}$ his treatise, "Geschichte des Schul. und Bildungslebens 1 im alten Freiburg bis zum 17 Jahrhundert" (Freiburger Geschichtsblätter, III.), F. Heinemann speaks on pp. 138-144 of the beginnings of the art of printing in Friburg (Switzerland). Deviating from the usual supposition, which considers Abraham Gemperlin the first Friburg printer, and places the date of the beginning of printing in this town in the year 1584 , Heinemann, supported by researches into the archives, thinks it possible to ante-date the commencement of the art of printing in Friburg by half a century, assigning to it the year 1543. According to him the first printer was a certain Hypocras named Hypocras. The manuscript sources upon which Heinemann relies are the council-minute books in the Friburg state-records.

This result stimulated me to make fresh investigation. I have applied numerous tests to the date of the beginning of printing in Friburg, the results of which $I$ have laid down in my Mélanges d'llistoire. fribourgoise, I. (1896), p. 3, et seq.

In the first place, I established the fact that Heinemann did not base his interpretation on the original text of the minutes, but on faulty and imperfect extracts. In the council-minutes of I 543 and 1544 there is certainly the speech of a book-printer, Hypocras; but he was, according to the testimony of the council-minutes themselves, a book-printer in Bern and a bookseller in Friburg (Hypocras of Bern, the bookseller; Minutebook, v. 3, January, 1543, and 7 th November, I544). In the section just quoted of the minute-book (v. J., I 544) it is, moreover, repeatedly stated that Hypocras had imported the books which he offered for sale, from outside (velich . . . bücher in ir stad her gebracht und offenlich villgegeben hatt). The book which Heinemann states to have been printed in Friburg in the 
year 1544 in proof of his assertion (Die Geschichts des propheten Danielis oines Theyls in der Babilonischen gfengnus beschehen in sprizelt gesogen und gespilt durch ein Ersamme Burgerschafft su Fryburg in Uchtlardt) was, as the imprint proves, printed in Bern: "Printed at Bern in Uchtland by Mathia Apiario, 1545."

On these considerations, therefore, Heinemann's attempt to assign the beginning of the art of printing in Friburg to the year 1543 has completely failed.

It is true that there appears at first sight a second argument, which Heinemann brings forward to the support of his assertion. In the possession of the Cantonal Library are two small printed works in two separate editions, with the title: Katholische Gesaenger auf Weikrackten, Advent und Osteri, wie auch durck das ganse Fahr su gebrauchen; Gedruckt zu Freiburg im Uchtland (48 pp., 12mo.). The one has on the title-page the year 1570 ; the other, recording the place of printing (Friburg), but wanting date, is, undoubtedly an older edition, and might go back some twenty to thirty years earlier. In the second place, Heinemann relies on these data as a means to refer the beginning of the art of printing to the fifth decade of the sixteenth century.

Professor Gremaud has before now questioned the fact of the above-mentioned printed works belonging to the sixteenth century ; he omits, however, to make positive statements. The relatively modern type must strike one at the first glance, and it was not difficult on internal and external grounds to ascribe the type to the eighteenth century.

As the title of the book informs us, it contains Catholic hymns: these are mostly of comparatively recent date; the most recent dates from the end of the seventeenth century. This fact alone established, the year of printing the work, 1570 , is already proved erroneous; external reasons will give additional force and point to the established fact.

Comparison of a series of printed works issuing from Friburg presses during 1585 to 1700 , proved that the letters of the book assumed to have been printed in Friburg in 1570, as well as those of the undated edition, were not used in Friburg during the period in question. I was able to prove, on the contrary, a great resemblance to the letters of the Friburg printer Hautt (1712-72); I was enabled to identify a series of the same, and became convinced that both works emanated from Hautt's printing press somewhere during the years 1712-72. The remarkable resemblance of the dated work to Hautt's types 
between $174^{\circ}$ and $175^{\circ}$ has led me to the well-grounded conjecture that the figures of the year 1570 are a misprint for $175^{\circ}$, and that the book consequently belongs to the middle of the eighteenth century. The somewhat older undated edition should be assigned to about 1730 .

The statements which Heinemann makes about the negotiations for the establishment of a printing press at Friburg, about the censorship of the Jesuits, in which Friburg printing was cradled, and respecting the various presses and other matters, have a worthy claim upon our gratitude.

DR. K. HOLder. 